Thayer, R. H. \& Davis, G. T. (1948). Poult. Sci. 27, 176.

Thayer, R. H., Jaap, R. G. \& Penquite, R. (I944). Poult. Sci. 23, 555.

Thayer, R. H., Jaap, R. G. \& Penquite, R. (1945). Poult. Sci. 24, 483.

Thornton, P. A. \& Moreng, R. E. (1958). Poult. Sci. 37, 554.

West, J. W. (I 956). Poult. Sci. 35, 835 .

Wheeler, R. S., Hoffmann, E. \& Graham, C. L. (I948). Poult. Sci. 27, ro3.

White-Stevens, R. H. (1957). Vet. Rec. 69, 217.

\title{
Wild birds as human food
}

\section{By M. F. M. MeIklejohn (Editor, Scottish Birds), Department of Italian Language and Literature, University of Glasgow}

'And these are they which ye shall have in abomination among the fowls; they shall not be eaten, they are an abomination: the eagle, and the ossifrage, and the ospray, and the vulture, and the kite after his kind; every raven after his kind; and the owl, and the night hawk, and the cuckow, and the hawk after his kind, and the little owl, and the cormorant, and the great owl, and the swan, and the pelican, and the gier eagle, and the stork, the heron after her kind, and the lapwing, and the bat.' (Leviticus, XI, I3-I9). This 'Mosaic' prohibition, it will be noticed, is a list of birds which few of us would venture to eat even if it were not forbidden us, 'lapwing' being, of course, a mistranslation for 'hoopoe'. Few people, for example, can have eaten or thought of eating a hawk, with the exception of the fictional Federigo degli Alberighi in the Decameron, who served up his falcon (his last and most precious possession) to his lady at dinner, as a token of his love: Boccaccio, however, does not tell us if the meal was, gastronomically, a success. On the other hand more than one species of owl, although carnivorous, is edible; the little owl (Athene noctua) is eaten in Sardinia and the eagle owl (Bubo bubo) is said by the Persians to be a delicacy. Nevertheless the main principle in the above passage from the Old Testament still remains - that for a bird to be chosen as food for man it should be palatable.

We have three principles that govern the choice of birds as food: (I) ease of capture, (2) size, (3) palatability.

Ease of capture. It is obvious that birds which nest in colonies or consort in flocks will be easier to exploit, although many of these, being seabirds, are not necessarily very palatable. In our 'advanced' society there is only one surviving instance in Britain of the exploitation of a seabird colony for food and that is the annual raid by the men of Ness on Sula Sgeir, when young gannets (Sula bassana) are killed, cured and, under the name of 'gugas', are sent to Lewis men all over the world; but, within the memory of a young man (personal communication by Police Constable Calum Nicolson) the Shiant Isles were regularly visited by the people of Limervay in Lewis to kill the young puffins (Fratercula arctica) and the economy of St Kilda depended largely on seabirds, chiefly the fulmar (Fulmarus glacialis). On Tristan da Cunha a frequent Sunday dinner was another seabird, the great shearwater (Procellaria gravis), which could simply be extracted from its burrow, and on 
Heligoland kittiwakes (Rissa tridactyla) were made into a pie with oatmeal, especially in November and December, when the birds are fattest: they were said, however, to have a 'Greenland flavour' (Gätke, I 895). Ease of capture has resulted in the total extinction of several species, notably the great auk (Alca impennis), which early voyagers used to salt in barrels: they were so tame that they would walk up a plank or a sail stretched from the ship to the shore (Grieve, I885).

Birds that are numerous are sometimes caught accidentally, as with the albatrosses (Diomedea sp.) which are frequently taken on fishing lines by the Cape fishermen and, of course, eaten.

Birds which flock form an easy target and thus the galah, a species of cockatoo (Cacatua eos), which consorts in bands, is a common food in Australia. In Italy the species most commonly for sale in the markets are the skylark (Alauda arvensis) and the Italian sparrow (Passer italiae), of which whole parties may be captured simultaneously with the paretaio or clap-net. The once incredible numbers of the passenger pigeon (Ectopistes migratorius) perhaps paradoxically contributed to its extermination. In our own country, before proteins were cheaply available in tins, it was the flocking species that made the food of the poor countryman--the rook (Corvus frugilegus), house sparrow (Passer domesticus), starling (Sturnus vulgaris), and, at the seaside, the dunlin (Calidris alpina). A strange commercial exploitation of bird flocks was that of the thousands of scaup (Aythya marila) off the Leith sewage outlet: they used to be made, quite accurately, into 'wild duck paste'.

Mediterranean peoples have perfected the technique of trapping smaller birds. Several age-old Italian devices have been taken over by modern ornithologists, such as the paretaio or clap-net, and the roccolo, a permanent trap planted with bushes, resembling the 'Heligoland trap' to be seen at most bird observatories. In Egypt the indiscriminate use of bird-lime permits the profitable capture of small birds that occur singly: they are simply left on the trees until collected.

Size of birds. It is obvious that it is more economical to catch for food one large bird than one small bird, although small birds may be used as food if their capture is easy (see above). The size of a bird does not as a rule affect its palatability, as with eggs (Cott, I953 $a, b$, I 954), but large birds tend to be tough, as the adults of the mute swan (Cygnus olor) and the sheldrake (Tadorna tadorna), neither of which would adorn a banquet.

Palatability. Palatability is affected by the food of the bird itself: grain-eating and other vegetarian birds are the most delicious, e.g. the pheasant (Phasianus colchicus), but eaters of flesh and fish are rarely eaten by man. The capercailzie (Tetrao urogallus), which feeds largely on young pine-needles, is a typical bird whose flavour is affected by its food: it tastes of turpentine and to get rid of this unpleasant flavour in Sweden they soak the bird in sour milk: in Scotland they bury it. The widgeon (Anas penelope) is an excellent table bird when it has been grazing on grass, but is emetic when it has been feeding at a sewage outfall. Various fish-eating species were permissible food during Lent in the Middle Ages, since the birds themselves tasted of fish. Song thrushes (Turdus ericetorum) and blackbirds (T. merula) are delicacies in the Mediterranean countries in autumn when they have been eating grapes. 
I can trace only one instance of a bird being commonly eaten raw: this is the little auk (Plautus alle), which the unsqueamish Eskimos often eat immediately after capture, using the feathers as a napkin.

In the eating of birds, as in other branches of gastronomy, snobbery is sometimes a factor, as it doubtless was when emperors ate the tongues of nightingales. The ortolan (Emberiza hortulana), not a native of Britain, was a delicacy in France; thus British gourmets must eat ortolans, too. A thriving commerce in wheatears (Oenanthe oenanthe), existed in Sussex to satisfy this craving. A host may give his guests the eggs of the black-headed gull (Larus ridibundus), but they will always be referred to as 'plover's eggs'.

Avian by-products as food. 'The exploitation of wild birds' eggs for food has been very fully dealt with by Cott (1953 a,b, 1954). 'Wild birds whose eggs are used for food' he writes, 'belong mainly to large species and to those nesting colonially; in general the eggs of such birds are both accessible and palatable'. In other words, similar criteria are valid for the eating of wild birds' eggs as for the wild birds' themselves.

Bird's-nest soup provides the only example of avian saliva being used as food by man. The nests are those of a swiftlet (Collocalia sp.) and, as with other species of swift, much saliva goes into their composition. This species also is colonial.

There is mention in the Bible of birds' faeces being used as food. During the siege of Samaria by Ben-hadad, king of Syria, 'an ass's head was sold for fourscore pieces of silver, and the fourth part of a cab of dove's dung for five pieces of silver' (II Kings VI, 25).

Harmful effects of eating birds. There are instances in which the eating of birds' flesh may react unfavourably upon the human system. The hard meat of the wood pigeon (Columba palumbus), for example, is extremely binding and gamekeepers and other countrymen, eating a great many of them, have been seriously affected. The flesh of green pigeons of the genus Treron, after they have been eating figs, will turn the urine of the eater bright green, which has no harmful effect other than temporary alarm. An interesting example is that of the greenfinch (Chloris chloris), which is the only bird to eat the berries of the common garden shrub (Daphne mezereum): these fruit are presumably poisonous to other berry-eating birds, as they are to human beings. It is not known whether, if a man were to eat a greenfinch which had been taking this food, he himself would be poisoned. There is, however, one example of the food of a bird having had dangerous, or even fatal, effects on men eating the bird, the quail (Coturnix coturnix), after eating the seeds of hemlock (Conium maculatum) (Toschi, I959). Unless the use of poisonous insecticides is controlled, we may confidently expect in the future human fatalities caused by eating poisoned birds. There will always be someone who 'doesn't know better' and, after reading of a recent Scottish case in which a man mistook hemlock roots for celery and put them in his soup, one may be sure that a man's choice of diet is not always soundly governed by instinct. 
Boccaccio, G. (1353). Il Decamerone. [V. Branca, editor.] Florence: Le Monnier, I95 I-2.

Cott, H. B. (1953a). Ibis, 95, 409 .

Cott, H. B. (1953b). Ibis, 95, 643.

Cott, H. B. (1954). Ibis, 96, 129.

Gätke, H. (1895). Heligoland, an Ornithological Observatory. Edinburgh: David Douglas.

Grieve, S. (1885). The Great Auk or Garefowl. London: 'T. C. Jack.

Toschi, A. (1959), La Quaglia : Vita, Caccia, Allevamento. Bologna: Università di Bologna. 